\title{
PERUBAHAN ORGANISASI PERGURUAN TINGGI ISLAM DI INDONESIA DALAM MENGHADAPI PERSAINGAN GLOBAL: Belajar dari UIN Maliki Malang
}

\author{
Aries Musnandar \\ Fakultas Ekonomi Bisnis Universitas Brawijaya Malang \\ Telp.0811362625, email: raries.m1@gmail.com
}

\begin{abstract}
This article delineates the changes of Islamic higher education institution (university) in Indonesia whose explore use of several terms that signify Islam and education, and provides guidelines to clarify their use in educational concept discourses. Building on this, the article describes a typology of Islamic education and its associated institutions. Influences of globalization in terms of economics and technology are also discussed in this article. This enhances understanding of important conceptual differences that hinge upon subtle variations of language as in the distinction between education of muslims and for/muslims, and between teaching Islam and teaching about Islam. The article then seeks to elucidate a theoretical conception of "Islamic education," that takes into consideration the Islamic Holy Book Al Quran and Prophetic statements, along with commonly-held approaches to education in muslim history especially in Indonesia. The article concludes that key motivations and characteristics of a holistic and purposeful education program are shared between Islamic traditional education (in pesantren) and Western traditions or modern education until the present. The article also discusses on a dichotomy between sciences and Islamic subjects that have to be delivered both in public universities and education institution based-Islam. The discourse is being a very long discussion in Indonesia until today.
\end{abstract}

Artikel ini menyoroti perubahan bentuk dan orientasi perguruan tinggi Islam di Indonesia yang semula hanya berkutat masalah ilmu agama (Islam) semata kini diperluas meliputi ilmu umum atau sains sebagaimana misi yang diemban perguruan tinggi umum. Perubahan yang terjadi tidak terlepas dari karakteristik 
organisasi yang senantiasa dipengaruhi faktor internal dan eksternal yang satu dan lainnya saling terkait baik langsung maupun tidak langsung. Perubahan organisasi perguruan tinggi Islam menjadi suatu keniscayaan karena pengaruh perkembangan iptek dan demokrasi dan juga menghadapi persaingan global yang terjadi diberbagai sektor kehdupan. Perguruan tinggi di Indonesia dengan demikian dituntut agar lebih memenuhi kebutuhan masyarakat. Selama ini persoalan perubahan misi dan visi lembaga pendidikan Islam selalu terbentur pada pandangan dikotomik yang memisahkan antara sain dan ilmu agama yang sampai sekarang masih menjadi perdebatan seru. Padahal agama Islam membawa misi dan visi rahmatan lil alamin, sesuai dengan sandaran wahyu (al Quran dan Hadits). UIN Maliki Malang merupakan salah satu PTAI yang merubah format dari STAIN ke UIN dalam upaya menyelesaikan diskursus dikotomik keilmuan. Oleh karena itu artikel ini juga berupaya menyumbangkan ide dalam upaya membentuk pendidikan Islam yang ideal.

Key words: organization, organization change, Islamic higher education change, Islamic education dichotomy, ideal Islamic education

\section{Pendahuluan}

Hidup dan kehidupan di dunia ini senantiasa berubah. Sebagaimana diajarkan dalam agama bahwa kehidupan di akherat kelak adalah alam kekal - abadi, sedangkan kehidupan dunia ini adalah alam fana-sementara yang tidak terlepas dari perubahan. Pernyataan ini mengandung makna bahwa kehidupan di dunia bersifat relatif, tidak langgeng dan selalu terjadi dinamika berujung perubahan.

Dunia hari ini dalam suatu kondisi mengalami perubahan yang dinamis. Perubahan itu tidak hanya pada aspek-aspek fisik dari lingkungan seperti gedung baru, jalan baru, temuan baru untuk transportasi, sektor produksi bahkan di bidang hiburan, tetapi juga berbentuk konsep riil seperti nilai, tradisi dan ide sosial. Perubahan pada aspek non fisik dari sebuah kultur berlangsung tidak secepat perubahan aspek fisik, namun hal ini terjadi dalam upaya mengakomodasi perubahan-perubahan aspek fisik atau yang bersifat materi.

Nilai-nilai baru yang berkembang dalam dunia modern akan diikuti oleh pembentukan pola perilaku komunitas yang disesuaikan dengan nilainilai itu. Pada prinsipnya kehidupan masyarakat modern tidak terlepas dari dua pengaruh kembar yang cukup menentukan perubahan sesuatu konsep, nilai, ide, teori dan paradigma yaitu pengaruh demokrasi dan sains (Rice $\&$ Bishoprick, 1971: 76).

Kehidupan berorganisasi pun mengalami perubahan karena lingkungannya 
pun mengalami perubahan baik lingkungan sistem ekonomi, politik, maupun sosial dan budaya. Dalam konteks ini perubahan organisasi merupakan hal lumrah dan logis.

Tumbuh-kembang dan dinamika suatu kehidupan masyarakat bermula dari perilaku individu anggota masyarakatnya. Sebagaimana satu organisasi akan dipengaruhi oleh perubahan perilaku anggota organisasi, maka peran individu pada kehidupan masyarakat dapat mewarnai pola perilaku masyarakat. Dalam konteks ini (Luthans, 1992: 34), menyebutkannya dengan istilah perilaku organisasi. Hubungan perilaku organisasi terhadap teori organisasi berada pada tataran teoritis, sedangkan pengembangan SDM dan organisasi pada kawasan terapan.

\section{Landasan Keagamaan}

"Sesungguhnya Allah mencintai orang-orang yang berjuang di jalan-Nya dalam barisan yang teratur, mereka seakan-akan seperti suatu bangunan yang tersusun kokoh." (QS ash Shaff: 4).

Salah satu surat Madaniyah ini mengingatkan kita akan pentingnya berjamaah (berorganisasi) di dalam Islam. Penguatan organisasi (jamaah) memang dibutuhkan ketika Rasulullah SAW mendakwahkan Islam di Madinah. Sedangkan ketika di Mekkah dakwah Rasulullah SAW fokus pada pengokohan akidah umat Islam masa itu. Dalam surat ini, terdapat lima konsep besar yang harus ada untuk mewujudkan organisasi yang kokoh, yaitu, kesesuaian konsep dan pelaksanaan dalam organisasi, soliditas tim, ketepatan mengukur dan mengetahui kekuatan dan tantangan, konsep kesungguhan dalam bekerja dan berjuang, serta memiliki kader yang militan (kader yang solid). Ketika kita membuka kembali ayat-ayat yang terukir indah dalam surat ash Shaff ini, akan banyak sekali kandungan tentang manfaat serta konsep-konsep dalam berorganisasi, bekerja dalam sebuah barisan yang teratur dan kokoh.

Pertama, untuk mewujudkan organisasi yang kokoh diperlukan adanya kesesuaian konsep (perkataan) dan pelaksanaan (at tawafuq bainal qouli wal amal). Hal ini tercantum dalam surat ash Shaff ayat 1-3. Dijelaskan dalam ayat ini, bahwa seruan-seruan ini hanya ditujukan untuk orang-orang beriman dan tidak untuk semua orang. Artinya bahwa, sebagai orang beriman harus memahami dan melaksanakan hal tersebut. Selain itu, yang diseru di sini adalah orang-orang beriman bukan hanya satu orang beriman.dan di sinilah pesan konsep kejamaahannya (keorganisasiannya).

Kesesuaian antara konsep (perkataan) dan pelaksanaan artinya tidak 
hanya lihai merumuskan ide yang tidak diiringi dengan amal nyata. Justru keduanya harus berjalan dengan sinergi antara konsep dan pelaksanaan. Organisasi itu harus mempunyai konsep cara bekerja. Bukan hanya sekedar mempunyai kemampuan bekerja tetapi juga menguasai cara bekerja. Penguasaan cara bekerja memudahkan bagaimana mencapai tujuan.

Kedua, dalam ayat keempat surat ini disebutkan bahwa Allah SWT menyukai mukmin yang berjuang dalam sebuah bangunan yang kokoh. Ciri dari bangunan yang kokoh adalah seluruh komponen di dalamnya saling menguatkan satu dengan yang lain. Dapat dirinci, bahwa soliditas organisasi memiliki tiga cirri yaitu, masing-masing komponen didalamnya bisa menguatkan satu dengan yang lain, bersinergi dalam bekerja serta memiliki program yang jelas, termasuk pembagian pelaksanaan program (pembagian potensi dan pemanfaatan kemampuan). Dalam hal ini, diperlukan adanya ketepatan di dalam penempatan orang. Siapa yang harus jadi tiang, jendela, atap, dsb.

Ketiga, dalam surat ash Shaff ayat 5-9 dijelaskan tentang tantangan yang dihadapi oleh para nabi dan rasul. Dari ayat ini kita dapat mengambil pelajaran tentang perlunya untuk mengukur tantangan-tantangan yang akan dihadapi dalam kerja-kerja organisasi. Jika kita mengetahui ukuran tantangan itu, maka kita bisa membuat program yang bisa mengatasi tantangan tersebut. Kegagalan dalam mengukur tantangan yang akan dihadapi, akan mengakibatkan ketidakjelasan merumuskan tahap-tahap pelaksanaan amal sehingga bisa terjebak dalam suatu amal yang bersifat asal asalan. Tantangan yang perlu diukur adalah semua tantangan baik dari dalam maupun luar organisasi. Pada surat ash Shaff ayat 9 dijelaskan bahwa visi kerasulanlah yang bisa digunakan untuk mengeliminir tantangan-tantangan tersebut.

Keempat, dijelaskan bahwa untuk membangun sebuah organisasi yang kokoh diperlukan adanya sebuah konsep perjuangan organisasi. Konsep ini mengandung motivasi serta makna optimisme yang jauh dari konsep perjuangan yang 'menakutkan' (tidak realistis dan membuat komponen di dalamnya ragu dapat melaksanakannya atau tidak). Hal ini dapat dilihat pada surat ash Shaff ayat 10-13, yang menjelaskan indahnya sebuah konsep berjuang besungguhsungguh di jalan-Nya.

Kelima, dalam surat ash Shaff ayat 14 dijelaskan bahwa keberhasilan suatu perjuangan dalam organisasi juga ditentukan dengan ada tidaknya kader-kader militan di dalamnya. Militan ini terkait dengan makna komitmen, konsistensi, keseimbangan (tawazunitas), ketaatan serta kecintaan. Karena memang amal yang baik dari seorang kader organisasi tidak akan bisa terwujud 
tanpa lima hal di atas. Maka dengan memiliki kader yang militan, amal amal terbaik akan dihasilkan dalam organisasi. Sebagaimana kaum muhajirin yang demikian militan dalam mendampingi Nabi menjalankan tugas tanpa mudah dipengaruhi hal hal bersifat keduniawian.

Di dalam organisasi juga diperlukan adanya ruh (semangat) organisasi. Dan ruh organisasi ditentukan oleh sistem organisasi yang dimulai dengan visi dan misi organisasi, kualitas sang pemimpin, lingkungan dalam organisasi yang kondusif untuk bekerja optimal. Ruh organisasi juga bisa terlihat dari sejauh mana organisasi memadukan semangat dan ilmu yang dimiliki (Rangkuman ceramah Ustadz Rofi Munawar Lc; sumber wanvisioner.blogspot.com).

\section{Konsep Organisasi}

Hampir setiap manusia modern hidup dalam organisasi, namun apa yang dimaksud dengan organisasi? Mengapa dalam kehidupan modern orang memerlukan organisasi? Perubahan organisasi dalam era modern merupakan suatu keniscayaan karena memang kehidupan manusia di dunia secara alami adalah dinamis. Organisasi kemudian dimanfaatkan sebagai sarana manusia memperbaiki kualitas hidup. Kumpulan manusia di dalam organisasi tersebut yang membuat perubahan bentuk organisasi terjadi.

Terdapat beberapa teori dan perspektif mengenai organisasi, ada yang cocok sama satu sama lain, dan ada pula yang berbeda. Organisasi pada dasarnya digunakan sebagai tempat atau wadah dimana orangorang berkumpul, bekerjasama secara rasional dan sistematis, terencana, terorganisasi, terpimpin dan terkendali, dalam memanfaatkan sumber daya (uang, material, mesin, metode, lingkungan), sarana-parasarana, data, dan lain sebagainya yang digunakan secara efisien dan efektif untuk mencapai tujuan organisasi. Menurut para ahli terdapat beberapa pengertian organisasi sebagai berikut (sumber: Wikipedia.org, diakses 24 Januari 2012).

1. Stoner mengatakan bahwa organisasi adalah suatu pola hubunganhubungan yang melalui mana orang-orang di bawah pengarahan atasan mengejar tujuan bersama.

2. James D. Mooney mengemukakan bahwa organisasi adalah bentuk setiap perserikatan manusia untuk mencapai tujuan bersama.

3. Chester I. Bernard berpendapat bahwa organisasi adalah merupakan suatu sistem aktivitas kerja sama yang dilakukan oleh dua orang atau lebih

4. Stephen P. Robbins menyatakan bahwa Organisasi adalah kesatuan (entity) sosial yang dikoordinasikan secara sadar, dengan sebuah batasan yang relatif 
dapat diidentifikasi, yang bekerja atas dasar yang relatif terus menerus untuk mencapai suatu tujuan bersama atau sekelompok tujuan.

Sebuah organisasi dapat terbentuk karena dipengaruhi oleh beberapa aspek seperti penyatuan visi dan misi serta tujuan yang sama dengan perwujudan eksistensi sekelompok orang tersebut terhadap masyarakat. Organisasi yang dianggap baik adalah organisasi yang dapat diakui keberadaannya oleh masyarakat disekitarnya, karena memberikan kontribusi seperti; pengambilan sumber daya manusia dalam masyarakat sebagai anggota-anggotanya sehingga menekan angka pengangguran.

Orang-orang yang ada di dalam suatu organisasi mempunyai suatu keterkaitan yang terus menerus. Rasa keterkaitan ini, bukan berarti keanggotaan seumur hidup. Akan tetapi sebaliknya, organisasi menghadapi perubahan yang konstan di dalam keanggotaan mereka, meskipun pada saat mereka menjadi anggota, orang-orang dalam organisasi berpartisipasi secara relatif teratur.

Dalam konteks tulisan ini organisasi pada intinya diartikan sebagai sekelompok manusia yang bekerja sama untuk mencapai tujuan (Robbin, Bergman, Stagg, Coulter, 2003: 63). Dalam pengertian ini terkandung makna bahwa organisasi memiliki karakteristik yang meliputi; 1) sekumpulan manusia yang bekerja sama, dan 2) memiliki tujuan yang ingin dicapai bersama. Jadi kelompok manusia yang berkumpul dalam satu wadah ini bukan terbentuk secara alami atau secara kebetulan, tetapi terbentuk melalui kegiatan rekayasa yang disengaja. Selain itu, oleh karena sekelompok orang tersebut harus saling bekerja sama, dan juga harus mencapai suatu tujuan, maka harus ada yang mengkoordinir kegiatannya, sehingga dapat dicapai suatu titik temu dan dapat diarahkan pada tujuan yang diinginkan bersama. Orang yang mengkoordinir disebut dengan manajer, pekerjaan yang dilakukannya disebut dengan kegiatan manajemen. Itulah sebabnya kegiatan manajemen ada pada suatu organisasi, dan profesi manajer terdapat dalam organisasi tersebut. Tanpa organisasi, profesi manajer tidak diperlukan.

Mengapa dalam kehidupan modern orang harus hidup dalam organisasi? Organisasi dalam arti luas merupakan kumpulan anggota masyarakat (society) yang memiliki kepentingan tertentu yang disebut komunitas (community), Hal ini dikarenakan beberapa hal: 1) Manusia memerlukan penerus generasi. Untuk dapat meneruskan generasi maka manusia harus menikah dan kemudian terbentuklah keluarga, dari keluarga tersebut kemudian berbagai tujuan kehidupan bersama diberlakukan. 2) kondisi kehidupan yang makin kompleks, 
masalah yang makin kompleks, aturan, kebutuhan dan harapan yang makin kompleks. Dengan kondisi seperti tersebut, manusia tidak mungkin menjalani kehidupannya dan menyelesaikan berbagai masalahnya sendirian, manusia memerlukan orang lain dan kemudian karena semua manusia tidak dapat menyelesaikan kehidupannya sendirian maka kemudian berbagai masalah tersebut diselesaikan dalam bentuk-bentuk yang terorganisir.

Dari penjelasan di atas terbukti bahwa organisasi amat diperlukan dalam pencapaian suatu tujuan yang diinginkan bersama. Perlunya organisasi ini memungkinkan bentuk-bentuk organisasi bervariasi sesuai dengan peruntukannya. Pada dunia bisnis dan industri muncul organisasi perusahaan, di bidang kesehatan mewujudkan organisasi rumah sakit. Di sektor pendidikan, organisasi diejawantahkan dalam berbagai variasi model, misalnya sekolah, madrasah, pesantren dan universitas. Konsep organisasi pendidikan memiliki ciri khas tersendiri.Namun demikian seiring dengan perubahan zaman, terdapat pergeseran pada beberapa konsep tentang organisasi. Pergeseran tersebut umumnya dipengaruhi oleh kondisi eksternal yang makin kompetitif dan makin cepat berubah atau bergerak dengan cepat. Kondisi-kondisi tersebut kemudian mendorong organisasi untuk mampu menyesuaikan diri agar tetap dapat bertahan dalam kondisi yang dinamis. Sebagaimana mahkluk hidup, organisasi memiliki siklus pertumbuhan, yaitu lahir, berkembang, puncak karir, tua dan kemudian mati. Namun demikian, usia organisasi dapat diperpanjang melalui kegiatan perubahan. Konsep perubahan dalam organisasi tersebut digambarkan oleh Kasali (2006) sebagaimana Gambar 1.

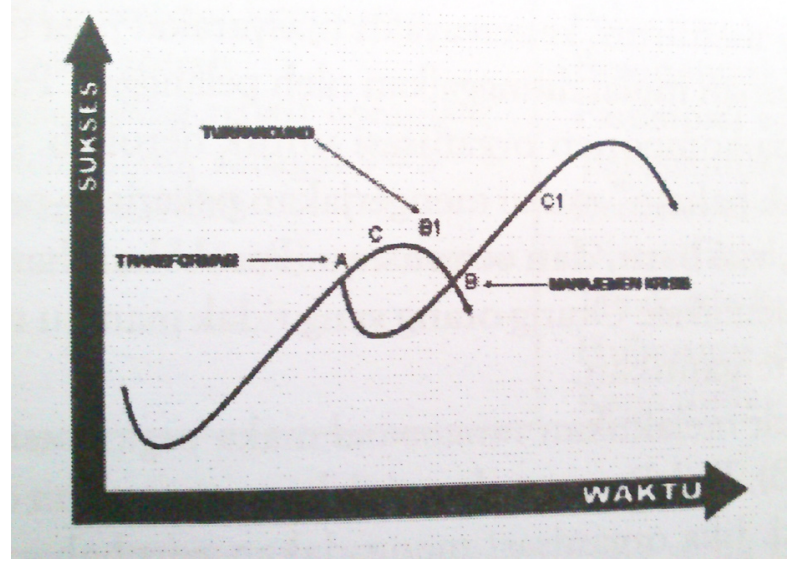

Gambar 1. Perubahan dalam organisasi (Kasali, 2006) 


\section{Perubahaan Organisasi sebagai Suatu Kebutuhan}

Organisasi dalam bentuk apapun selalu mengikuti proses perubahan yang terjadi agar kehidupan organisasi dapat terpelihara, berkelanjutan dan lebih bermanfaat. Garis lengkung menggambarkan siklus kehidupan organisasi. Lahir, kemudian memiliki kinerja yang menurun, karena saat awal kehidupan organisasi, masih memerlukan berbagai kebutuhan sumber daya, dan organisasi belum mampu memenuhi kebutuhan sumber dayanya sendiri, sehingga sumber daya harus disubsidi dari luar. Seiring dengan waktu, organisasi akan mulai memiliki reputasi, mendapatkan berbagai kepercayaan masyarakat, sehingga organisasi mulai mandiri dan mulai mampu memenuhi kebutuhannya sendiri. Demikian seterusnya semakin hari organisasi kian berkembang sampai pada titik tertentu. Titik A merupakan titik dimana organisasi berada dalam kinerja terbaik, reputasi sangat tinggi, kepercayaan masyarakat sangat baik, produk yang diluncurkan merupakan produk yang sangat kompetitif. Pada saat inilah yang terbaik dalam mengadakan perubahan organisasi. Organisasi harus mampu memperkirakan bahwa apa yang unggul dan disukai masyarakat saat ini belum tentu disukai masyarakat pada masa datang. Perubahan dilakukan ketika organisasi berada pada titik A dalam performa puncak, tidak akan terasa berat, organisasi sedang, dan perubahan dapat dilakukan secara evolutif.

Titik C merupakan titik balik organisasi, kinerja organisasi mulai turun, namun kepercayaan masyarakat masih tinggi dan produk-produk masih memiliki daya kompetitif, namun jika kondisi ini dibiarkan terus maka kinerja organisasi lambat laun akan habis dan menurun, kemudian akan ditinggalkan oleh masyarakat dan selanjutnya akan mati. Jika organisasi mau memperpanjang umurnya, maka organisasi harus melakukan perubahan secara revolusioner. Titik B1 merupakan titik perubahan yang dilakukan organisasi dengan revolusioner, yang diistilahkan dengan turnaround, atau "balik arah”. Perubahan yang dilakukan akan terasa berat, kinerja organisasi sedang menurun, kepercayaan masyarakat juga dalam kondisi menurun, produk dan layanan mulai ditinggalkan oleh pelanggan. Pada kondisi ini organisasi harus memaksa komponen organisasi untuk berubah. Seluruh komponen organisasi "berubah haluan" mulai mengerjakan pekerjaan-pekerjaan baru, tradisi baru, sistem baru, visi baru, dan seterusnya. Perubahan harus dilakukan secara revolusioner dan memaksa. Orang-orang yang tidak mampu menyesuaikan diri akan tertinggal atau tergantikan.

Jika organisasi tidak melakukan turnaround maka organisasi akan masuk ke manajemen krisis (titik B). Titik B merupakan titik harapan terakhir dari 
organisasi untuk berubah atau mati. Jika organisasi mengadakan perubahan pada titik B ini maka berlaku hukum sebagaimana pada turnaround tetapi jauh lebih tegas, dan harus dijalankan dalam kurun waktu cepat dan program sangat jelas. Perubahan dilakukan dalam konsep "ya atau tidak", tidak ada tawar menawar lagi, karena organisasi berada dalam ambang kematian.

Apabila organisasi mampu berubah maka organisasi akan hidup kembali atau memiliki usia panjang sehingga organisasi tersebut akan mampu bertahan dalam perubahan lingkungan yang terus berkembang. Organisasi kampus seperti Oxford University di Inggris, Leiden University di Belanda, Harvard University, dan Massachuset Institue of Technology di Amerika Serikat, Universitas Al Azhar di Mesir, merupakan organisasi pendidikan yang bertahan ratusan tahun dan masih memiliki produk-produk pendidikan yang kompetitif. Hal ini hanya mungkin terjadi manakala organisasi pendidikan itu meninggalkan karakteristik organisasi tradisional dan menerapkan konsep organisasi baru yang modern melalui telaah filosofis terkait dengan perubahan paradigma hidup masyarakat.

Perubahan yang terjadi membuat konstruk organisasi tradisional bermetamorfosis dan akhirnya melahirkan suatu organisasi baru. Karakteristik organisasi ini berbeda dengan organisasi tradisional (Robbin, Bergman, Stagg, Coulter, 2003: 65). Perbedaan antara organisasi tradisional dengan baru termaktub dalam Tabel 1 berikut ini:

Tabel 1. Perbedaan karakteristik organisasi tradisional dan baru

\begin{tabular}{|l|l|}
\hline Organisasi tradisional & Organisasi Baru \\
\hline Stabil & Dinamis \\
\hline Tidak fleksibel & Fleksibel \\
berpusat pada pekerjaan & Berpusat pada keterampilan \\
Berorientasi individual & Pekerjaan di definisikan sebagai tugas \\
Pekerjaan yang permanen & tugas yang harus dikerjakan \\
Berorientasi pada perintah & Berorientasi tim \\
Manajer selalu membuat keputusan & Pekerjaan yang temporal \\
Berorientasi pada aturan & Berorientasi pada pelibatan \\
Lingkungan kerja yang relatif homogen & Partisipasi seluruh pekerja dalam \\
Jam kerja didefinisikan sebagai 9 -5 & pengambilan keputusan \\
Hubungan yang hirarkhis & Berorientasi pada pelanggan \\
Fasilitas kerja ada pada jam-jam tertentu & Diversifikasi lingkungan kerja \\
& Tidak ada batas waktu kerja \\
Hubungan dua arah dan jaringan \\
Kerja dimana saja dan kapan saja
\end{tabular}


Dalam konteks ini pemahaman tentang seluk beluk organisasi memang hal yang mendasar terutama terkait dengan implementasi konsep manajemen. Manajer senatiasa mengantisipasi perubahan-perubahan dalam lingkungan yang akan mensyaratkan penyesuaian-penyesuaian disain organisasi diwaktu akan datang. Perubahan-perubahan dalam lingkungan organisasi dapat disebabkan oleh kekuatan internal dan kekuatan eksternal. Berbagai kekuatan eksternal dapat menekan organisasi untuk mengubah tujuan, struktur dan operasinya. Sedangkan perubahan dari faktor seperti tujuan, kebijakan manajer, sikap karyawan, strategi dan teknologi baru juga dapat merubah organisasi.

\section{Cara Penanganan Perubahan}

Perubahan-perubahan lingkungan dan perkembangan sosial seperti iklim demokrasi, kemajuan sains dan teknologi disertai dinamika internal organisasi turut andil secara optimal dalam membentuk organisasi baru dan meninggalkan organisasi tradisional. Cara menangani perubahan organisasi memerlukan berbagai pendekatan atau cara yang dapat dilakukan bagi organisasi yang berubah. Cara pertama adalah konsep perubahan reaktif dan yang kedua program perubahan yang direncanakan (Planned Change). Pada cara pertama biayanya murah dan sederhana serta ditangani secara cepat, di mana manajer akan memberikan reaksi setelah masalah terjadi. Misalnya bila peraturan pemerintah baru mensyaratkan perusahaan untuk mempunyai perlindungan terhadap kebakaran mungkin manajer membeli alat-alat kebakaran. Pendekatan yang kedua atau juga disebut sebagai proses produktif, Thomas dan Bennis mendefinisikan perubahan yang direncanakan sebagai perencanaan dan implementasi inovasi struktural, kebijaksanaan secara sengaja. Pendekatan ini tepat bila keseluruhan atau sebagian besar satuan organisasi menyiapkan diri untuk menyesuaikan dengan perubahan. Berbagai perubahan tersebut kemudian melahirkan berbagai konsep tentang organisasi. Mulai dari organisasi yang sangat mengandalkan pemimpin sampai dengan organisasi yang paling tidak mengandalkan pemimpin. Keseluruhan konsep organisasi tersebut digambarkan sebagaimana pada gambar 2 .

Autocracy adalah organisasi yang mengandalkan "kekuatan" pemimpin. Kewenangan pemimpin tinggi, bila pemimpin tidak mengijinkan maka tidak boleh dilakukan begitu sebaliknya. Sedangkan di sebelah kanan adalah organisasi Egalitarianism. Pada organisasi ini seluruh keputusan ada di tangan anggota organisasi, hampir tidak diperlukan pemimpin, tugas pemimpin hanya memfasilitasi saja terhadap diambilnya sebuah keputusan. Sedangkan 
diantara autocracy dan egalitarianism ada organisasi bureocracy (birokrasi), system, decentralization (desentralisasi), collegialism dan federations (federasi).

Jenis organisasi birokrasi berstruktur hirarkis, masing-masing orang mengepalai sub organisasi tertentu, satu sub organisasi kemungkinan akan memiliki sub-sub organisasi yang lain. Organisasi birokrasi bersifat sentralisasi. System merupakan jenis organisasi yang mensinkronkan proses pada satu sub bagian (orang) dengan sub bagian (orang lain) sehingga membentuk suatu proses yang berjalan baik. Sinkronisasi mengarah untuk mencapai tujuan yang lebih besar dari organisasi. Desentralisasi merupakan jenis organisasi yang bersifat setara antara satu sub organisasi dengan sub organisasi lain dalam satu organisasi. Masing-masing satu sub organisasi dipimpin oleh satu orang pemimpin. Masing-masing pimpinan sub organisasi bersifat setara. Organisasi Collegialism merupakan organisasi yang memiliki struktur kolegial dalam mencapai tujuannya. Pada jenis organisasi ini kedudukan orang-orang yang ada di dalam organisasi lebih bersifat setara, yang mana hubungan sesama anggota organisasi layaknya kolega. Sedangkan pada organisasi Federasi, pemimpin pada tataran sub organisasi memiliki wewenang mutlak layaknya pemimpin pada organisasi utama.

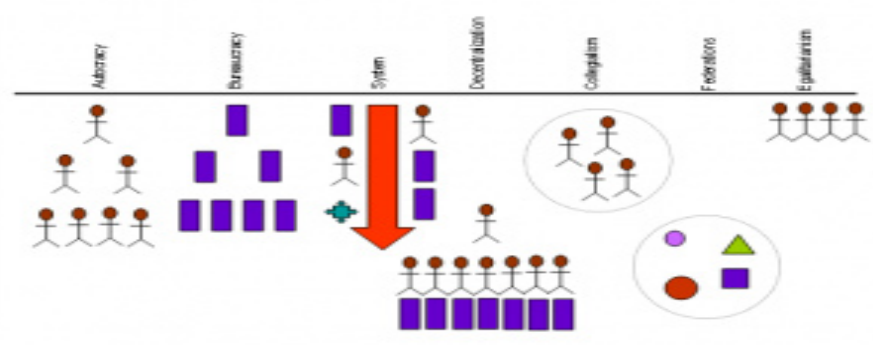

Gambar 2. Macam-macam konsep organisasi (Kasali, 2006)

\section{Perguruan Tinggi Islam di Indonesia}

Secara historis, Perguruan Tinggi Agama Islam (PTAI) khususnya IAIN, lahir dari peleburan PTAIN (Perguruan Tinggi Agama Islam Negeri) yang berkedudukan di Yogyakarta dan mengacu PP. No. 34/ 1950 dan ADIA (Akademi Dinas Ilmu Agama) Jakarta berdasarkan Penetapan Menteri Agama No. 1 tahun 1957 Tgl. 1 Januari 1957. Unifikasi kedua lembaga pendidikan tersebut menjadi IAIN didasarkan atas Peraturan Presiden No. 77 tahun 1960 tanggal 9 Mei 1960, dengan sebutan lain "al Jami'ah al Islamiah al Hukumiyah". 
Pada awalnya, pendirian IAIN hanya dimaksudkan sebagai kelanjutan dari program "memodernisasi" pendidikan Islam tradisional dan mempersiapkan tenaga-tenaga yang dapat mengisi tugas-tugas di bidang keagamaan. Namun, kini tujuan tersebut telah mengalami pergeseran dan perluasan misi, sejalan dengan perkembangan IAIN itu sendiri dalam menjawab tuntutan zaman. Bahkan secara institusional, selain terdapat 14 IAIN di Indonesia, hampir semua IAIN cabang yang ada selama ini telah diubah menjadi STAIN (Sekolah Tinggi Agama Islam Negeri). Kendatipun demikian, tampaknya pengembangan kelembagaan tersebut belum menjamin lembaga pendidikan tinggi itu untuk dapat menjadi tempat belajar dengan predikat academic excellence. (Sumber:http:// suyitno69.multiply.com/journal/ diakses 29-10-2011).

Kekhawatiran tersebut sesungguhnya telah menggambarkan betapa kepercayaan terhadap diri sendiri di kalangan umat masih lemah. Selain itu juga menunjukkan bahwa sampai saat ini belum ada kesepahaman tentang apa sesungguhnya yang disebut ilmu ke- Islam-an itu sendiri. Tidak sedikit orang masih terkungkung oleh pemahaman bahwa yang disebut dengan ilmu Agama Islam adalah ilmu syariah, tarbiyah, ushuluddin, dakwah dan adab, sedangkan lainnya bukan masuk kategori ilmu Agama Islam.

Sementara itu perguruan Tinggi Islam yang terpisah dari PTAI bermula sejak dirintisnya Sekolah Tinggi Islam oleh Mohammad Hatta dan M. Natsir pada bulan Juni 1945, yang kini menjadi UII di Yogyakarta. Perintisan itu sungguh memberikan arti mendalam bagi perintisan intelektualitas muslim di Indonesia hingga detik ini. Pesatnya perkembangan jaman yang membawa begitu banyak problematika hidup dapat diusahakan untuk mendapatkan ilmunya melalui lembaga-lembaga pendidikan khususnya Perguruan Tinggi Islam. Karena ditempat itulah, pengkajian terhadap suatu masalah mendapatkan porsi yang jauh lebih banyak dibanding jenjang pendidikan lainnya. Namun demikian, fakta juga menyebutkan bahwa tak sedikit dari PTAI yang justru hanya menjadi beban bagi umat. Ia tidak melahirkan kader dan tidak memberikan sumbangsih bagi kehidupan umat. Untuk itu, harus ada pemikiran visioner yang memiliki visi yang berlandaskan nilai-nilai ke-Islaman, sehingga diharapkan antara umat dan mahasiswa muslim secara berkesinambungan saling memberikan kontribusinya. Dalam hal ini, aspek dakwah kian menjadi sorotan tajam sejumlah lembaga pendidikan Islam untuk terus dikembangkan menjadi media utama gerak langkah perguruan tinggi (Natsir,sumber: $h t t p: / /$ stidnatsir.ac.id/index.php diakses 29-10-2010).

Perguruan tinggi merupakan organisasi atau lembaga pendidikan yang 
senantiasa dituntut untuk mengikuti perubahan. Hal ini karena perguruan tinggi itu sendiri adalah institusi pencetak agen-agen perubahan. Perubahanperubahan tersebut dilakukan agar perguruan tinggi mampu mengikuti perkembangan zaman yang semakin cepat melaju.

Bentuk-bentuk perubahan yang dilakukan oleh perguruan tinggi sangat variatif. Biasanya disesuaikan dengan visi dan misinya dan faktor-faktor pendorong lain. Baik dorongan yang berasal dari internal maupun eksternal perguruan tinggi itu sendiri. Di antara faktor tersebut ada yang didorong oleh keinginan internal para pengelola kampus untuk melakukan perubahan, ada pula yang didorong oleh pihak eksternal. Selain itu juga ada yang disebabkan karena bertemunya dua dorongan itu secara bersama-sama. Sehingga menyebabkan adanya gerakan yang serentak antara kepentingan internal dan eksternal perguruan tinggi (Sumber: http://ukpm-kronika.blogspot.com/2010/10/sekilasperjalanan-metamorfosis-stain.html. diakses 30-10-2010).

Menghadapi peradaban modern dewasa ini, yang perlu diselesaikan adalah persoalan-persoalan internal pendidikan Islam yaitu (1) persoalan dikotomik, (2) tujuan dan fungsi lembaga pendidikan Islam, (3) persoalan kurikulum atau materi. Ketiganya saling terkait satu sama lain yang harus diselesaikan secara simultan agar bentuk baru organisasi (lembaga) pendidikan Islam menuju pada integrasi antara ilmu agama dan ilmu umum. Dalam konsep Islam segenap alam semesta dan jagad raya ini beserta isinya termasuk ilmu pengetahuan (fenomena alam dan sosial adalah satu yaitu berasal dari, milik dan kuasa Allah SWT).

Secara makro persoalan yang dihadapi lembaga PTAI negeri dan swasta ketika itu adalah bagaimana sistem pendidikan Islam mampu "membaca" dan relevan dengan dinamika perubahan masyarakat. Untuk itu diperlukan rancangan atau disain yang relevan dengan perkembangan dan kebutuhan masyarakat. Kemudian disain pendidikan Islam tersebut dapat dan mampu ditransformasikan atau diproses secara sistematis dalam masyarakat. Persoalan pertama ini lebih bersifat filosofis, yang kedua lebih bersifat metodologis. Pendidikan Islam perlu menghadirkan konstruksi pada dataran wacana filosofis dan metodologis. PTAI cukup lama "terjebak" dalam tataran dikotomik seperti paparan di atas, tidak semua PTAI siap menerima integrasi keilmuan. Sehingga sebagian PTAI baik negeri maupun swasta masih tetap bertahan sebagai lembaga pendidikan Islam (IAIN-STAIN) yang para lulusannya diharapkan mampu mengisi bidangbidang keagamaan secara lebih baik. Dengan demikian konsentrasi atau fokus lembaga pendidikan Islam ini pada" ilmu keislaman” semata. 
Berbeda dengan di beberapa tempat lain, STAIN Malang yang kini telah berubah menjadi Universitas Islam Negeri Malang berusaha memformat diri menjadi lembaga pendidikan tinggi Islam ideal. Pikiran-pikiran yang pijakan selama ini adalah bahwa perguruan tinggi Islam seharusnya mampu mengantarkan mahasiswa memiliki empat kekuatan, yaitu: (1) kedalaman spiritual, (2) keagungan akhlaq, (3) keluasan ilmu dan (4) kematangan professional. Untuk membangun semua kekuatan itu, UIN Malang berusaha menggabungkan tradisi pesantren dan tradisi perguruan tinggi, dan itulah nantinya yang diharapkan lahir sosok perguruan tinggi Islam yang ideal. Selama ini perguruan tinggi lebih menekankan aspek akademik, sedangkan pesantren lebih mengedepankan akhlak dan spiritual lewat kultur yang dikembangkan. Jika kedua kekuatan ini (tradisi kampus dan pesantren) dipadukan maka diharapkan melahirkan sosok pendidikan yang lebih mendekati ideal sebagaimana yang ditunggu-tunggu kehadirannya oleh umat Islam di Indonesia (Sumber: http://uin-malang.ac.id/ diakses 25 Oktober 2010).

Kebijakan pemerintah berupa pemberian otonomi pendidikan dan otonomi daerah yang segera diberlakukan, mau tidak mau menuntut lembaga pendidikan, termasuk perguruan tinggi agama Islam, memiliki kemandirian, terbuka dan peduli dengan tuntutan zaman, dan mampu berkompetisi dengan lembaga pendidikan lainnya. Kemandirian harus ditempuh dan tidak boleh lagi bersikap menunggu dari atas. Mereka seharusnya tidak patut sekedar melakukan peran-peran sebagai pelaksana sebagaimana yang terjadi pada masa lalu. Menghadapi suasana yang serba terbuka di alam demokratis, orang akan melakukan pilihan-pilihan rasional. Orang tidak akan hanya melakukan pilihan atas dasar hubungan paternalistik maupun juga atas dasar loyalitas kelompok atau paham/ideologi tertentu. Selain itu bahwa penghargaan terhadap perguruan tinggi oleh masyarakat tidak lagi semata-mata didasarkan pada tingkat status yang diberikan oleh pemerintah seperti berstatus negeri dan swasta; berakreditasi A, B atau C. Masyarakat akan semakin realistis dalam memilih perguruan tinggi. Tentu, perguruan tinggi yang dipilih adalah yang benar-benar mampu memberi bekal hidup dan nilai tambah bagi lulusannya. Oleh karena itu, perguruan tinggi yang ingin berdiri tegak harus lebih terbuka dan mampu melihat tuntutan riil masyarakat.

Di sisi lain mahasiswa dan alumni PTAI umumnya cenderung berfikir normatif, kurang mampu memahami konteks dan substansi empiris dari persoalan agama, sehingga berakibat pada kekurangmampuan mereka mengemukakan alternatif penyelesaian masalah yang sifatnya realistik. Pada 
bagian lain, materi pengajaran yang berkaitan dengan pandangan-pandangan keagamaan, hendaknya juga berorientasi pada situasi nyata yang dihadapi oleh umat dewasa ini.

Pola pendidikan PTAI (IAIN-STAIN) termasuk tentu PTAI Swasta selama ini hanya menekankan kemampuan untuk memahami serta mengulangulang pengetahuan yang sudah ada dan mengabaikan kemampuan untuk mengembangkan diri bagi pengetahuan baru. Untuk itulah diperlukan kerja sama interdisipliner pada setiap cabang ilmu pengetahuan (Sumber: http:// uin-malang.ac.id diakses 28 Oktober 2010). Di sinilah kemudian konsep integrasi ilmu pengetahuan muncul. Dari pembahasan diatas dapat disimpulkan bahwa lembaga pendidikan Islam perlu dan mesti mampu mengembangkan kualitas pendidikannya sedemikian rupa, sehingga memenuhi kebutuhan masyarakat yang selalu berubah karena dinamikanya menuntut demikian. Lembaga-lembaga pendidikan Islami harus dapat menyiapkan sumber insani yang lebih handal dan memiliki kompetensi yang diperlukan untuk dapat hidup bersama di dalam ikatan masyarakat modern.

\section{Globalisasi dan Tantangan Perguruan Tinggi}

Membahas tentang globalisasi penting diungkap para tokoh yang menginspirasi merebaknya fenomena global dimuka bumi ini baik secara sosisal budaya, ekonomi maupun teknologi. Dalam tulisan ini akan dikemukakan pemikiran dari tiga pemikir masa depan (futurist) yakni, John Naisbiit, Alvin Tofller dan Samuel Huntington. Ketiga futurist ini walau menyoroti fenomena dari berbagai aspek yang bervariasi namun ketiganya sama-sama mengkaitkan temuannya dalam konteks perubahan global dan tantangan yang dihadapi dunia.

John Naisbiit misalnya sepuluh tahun sebelum menerbitkan buku "Megatrends 2000" tepatnya tahun 1982 ternyata dia juga menulis buku serupa yaitu "Megatrends" (tanpa 2000).

Buku ini menampilkan sepuluh poin penting yang merupakan prediksinya dalam melihat kehidupan masyarakat dunia kedepannya:

1. Masyarakat Industri $\rightarrow>$ menjadi masyarakat Informasi

2. Teknologi Paksa $\rightarrow>$ menjadi High Tech / High Touch

3. Ekonomi Nasional $\rightarrow>$ menjadi Ekonomi Dunia

4. Jangka pendek $\rightarrow>$ menjadi Jangka Panjang

5. Sentralisasi $\rightarrow>$ menjadi Desentralisasi

6. Bantuan Institusional $\rightarrow>$ menjadi Bantuan Diri 
7. Demokrasi Representatif $->$ menjadi Demokrasi Partisipatif

8. Hierarki $\rightarrow>$ menjadi Jaringan

9. Utara $\rightarrow>$ menjadi Selatan

10. Salah satu $\rightarrow>$ menjadi Pilihan Berganda

Beberapa hal dalam poin-poin di atas sudah kita rasakan bersama sebelum tahun 2000 di Indonesia. Contohnya no. 1 di atas, bahwa masyarakat dunia akan berubah dari masyarakat Industri menjadi masyarakat informasi. Dimulai dengan meledaknya lulusan TI yang diiming-imingi dengan gaji tinggi dan label "profesi calon menantu idaman", berkembangnya industri surat kabar dan majalah yang dibebaskan dari perizinan (SIUP). Beberapa poin lainnya dirasa masih relevan hingga sekarang. Misalnya, dari sentralisasi ke desentralisasi. Sistem pemerintahan kita pun berbenah diri dari arogansi pusat ke pembagian wewenang sehingga menciptakan kewenangan penuh di daerah.

Sepuluh tahun kemudian Nasibit pun menulis megatrends berikutnya, yang kita kenal dengan Megatrends 2000. Sebuah megatrends millenium (mille, bahasa Latin $=$ ulang tahun ke-1000). Buku ini lebih banyak mengisahkan tentang peluang dan sisi positif dari perubahan dunia. Hal hal manis sebagai penghibur orang-orang yang membacanya. Naisbitt menyebut "orang-orang yang melaporkan berita buruk hanya menjalankan pekerjaan mereka." Orang ini juga menyebutkan, bahwa terobosan yang paling menggairahkan dari abad ke-21 akan terjadi bukan karena teknologi, melainkan karena konsep yang meluas dari apa artinya menjadi manusia. Sebuah pergeseran yang menempatkan manusia sebagai faktor produksi dalam revolusi industri, menjadikan manusia sebagai subjek pembangunan itu sendiri.

Apa yang Naisbitt ramalkan tentang 10 tahun berikutnya itu, Megatrends 2000 adalah sebagai berikut: Megatrend: perubahan sosial, ekonomi, politik, teknologi yang besar (yang) berjalan lebih lambat, pengaruhnya cukup lama (7-8 tahun/lebih). Contoh: John Naisbit (1990-an) tentang masalah sosial:

1. Boom Ekonomi Global tahun 1990-an

2. Renaisans dalam Seni

3. Munculnya Sosialisme Pasar-Bebas

4. Gaya Hidup Global dan Nasionalisme Kultural

5. Swastanisasi Negara-negara makmur

6. Kebangkitan kawasan Pasifik

7. Dasawarsa peran Wanita dalam Kepemimpinan

8. Era Biologi 
9. Kebangkitan relijius Millenium Baru

10. Kejayaan Individu

Dari sepuluh prediksi Naibiit ini globalisasi yang terkait persoalan sosial ekonomi dan budaya telah mewujud nyaris sempurna dan mengemuka sebagai titik tekan perubahan dunia.

\section{Alvin Toffler}

Alvin Toffler adalah futurist berikutnya yang merupakan tokoh yang mempunyai pemikiran unik tentang peradaban manusia yang akan datang. Manusia mengharapkan masa depan yang lebih baik memberikan suatu makna tersendiri, memberikan harapan yang lebih baik. Tetapi manusia itu sendiri tidak dapat mengelak dari apa yang disebut dalam konsep Toffler sebagai perubahan. Gelombang perubahan pertama, kedua, dan ketiga. Kemungkinankemungkinan yang dihadapi manusia sekarang ini adalah kemungkinan semu. Konteks kehidupan yang melanda kehidupan manusia saat ini tidak lepas dari konteks kehidupan masa lalu. Jadi apa yang pernah diperbuat oleh manusia masa lampau mempunyai korelasi pada masa depan manusia. Dalam bukunya "The Third Wave" (1980) disebutkan bahwa ada tiga era di dunia ini yakni, era pertanian, era industri dan era informasi.

Menurut Toffler era informasi memasuki kancah perubahan peradaban dunia setelah James Watt menemukan mesin uap yang menandakan era industri. Dengan ditemukannya mesin uap akhirnya dunia mampu menciptakan mesinmesin berat yang kemudian merubah tata cara dan tata pandang manusia dalam beraktifitas baik dalam aspek ekonomi (kapitalis), sosial budaya maupun aspek kehidupan manusia lainnya. Sejalan perkembangan teknologi yang demikian cepat, informasi kian memegang peran penting dalam berubahnya berbagai sector kehidupan manusia. Mobilitas manusia memerlukan aksesibilitas informasi yang cepat dan akurat, dan manusia mulai tergantung dengan perkembangan produk teknologi informasi. Maka dimulailah era informasi yang membawa perubahan dahsyat dalam berbagai aspek kehidupan masyarakat menembus batas ruang dan waktu.

\section{Samuel Huntington}

Menurut Samuel, peradaban dunia yang bervariasi ini pada akhirnya akan mengalami apa yang disebutnya sebagai "Clash of Civilization", Clash berarti pertentangan atau benturan, jadi akan ada semacam pertentangan 
antara peradaban yang merupakan sebuah entiti kultural menggantikan entitas negara yang konvensional. Akan ada sekitar 8 sampai 10 peradaban besar yang nantinya akan mendominasi dinamika politik dan konflik di dunia.

Masing-masing entitas "peradaban" tersebut memiliki dinamika sejarah yg bergesekan dengan entiti lainnya. Barat misalnya, memiliki persengketaan dengan dunia Islam, Sino, sedikit dengan Hindu dan Orthodox dan sedikit sekali dengan Amerika Latin dan Afrika. Dan Islam-lah yang memiliki hubungan persengketaan terbanyak, dengan Barat, Orthodox dan lain-lain. Dalam tulisannya di majalah Newsweek Special Davos Edition (2001) yang berjudul "The Age of Muslim Wars", Huntington mencatat: "Terjadinya kemungkinan 'benturan peradaban' kini telah hadir." Ia juga menegaskan, "Politik global masa kini adalah zaman perang terhadap muslim." Tulisan Huntington di Newsweek itu meneguhkan kembali tesis lamanya (Clash of Civilizations). Ia menekankan bahwa konflik antara Islam dan Kristen, baik Kristen Ortodoks maupun Kristen Barat adalah konflik yang sebenarnya. Adapun konflik antara Kapitalis dan Marxis hanyalah konflik yang sesaat dan bersifat dangkal. (Huntington, 1996: 209). Langgengnya konflik antara Islam dan Barat, lanjut Huntington, disebabkan adanya perbedaan hakikat dari Islam dan Barat serta peradaban yang dibangun atas dasar keduanya.

Di satu sisi, konflik antara Islam dan Barat merupakan produk dari perbedaan, terutama konsep muslim yang memandang Islam sebagai way of life, yang menyatukan agama dan politik. Ini bertentangan dengan konsep Kristen tentang pemisahan kekuasaan Tuhan dan kekuasaan raja (sekularisme). Di sisi lain, konflik itu juga merupakan produk dari persamaan. Keduanya merasa sebagai agama yang benar. Keduanya sama-sama agama misionaris yang mewajibkan pengikutnya untuk mengajak "orang kafir" mengikuti ajaran yang dianutnya. Islam disebarkan dengan penaklukan-penaklukan wilayah dan Kristen pun juga demikian; keduanya juga mempunyai konsep "jihad" dan "crusade" sebagai perang suci (Huntington, 1996: 210-211). Dengan cara pandang Huntington seperti itu, bisa dipahami bagaimana sensitifnya Barat dalam melihat perkembangan dunia Islam, dalam berbagai bidang. Dalam dialog dengan Anthony Giddens, Huntington menyebut data dari majalah The Economist, yang memaparkan bahwa dari 32 konflik besar yang terjadi tahun 2000, lebih dari dua pertiganya adalah konflik antara muslim dengan nonmuslim" (Sumber: http://alislamu.com/artikel/ diakses 23 Januari 2012).

Dari ketiga pemikir dan futurist tersebut diatas dapat kita tarik suatu benang merah bahwa perubahah terjadi demikian cepat dan merupakan 
keniscayaan. Perubahan yang mewujud itu bisa jadi dapat mencuatkan benturan peradaban dalam konteks ini maka dialog peradaban sangat diperlukan untuk menghadapi globalisasi dan tantangan yang dihadapi.

Perkembangan, perubahan dan dinamika dari sejumlah sektor kehidupan yang ditandai kemajuan pesat teknologi seperti dipaparkan di atas memungkinkan munculnya superioritas dan dominasi hegemoni apabila tidak dibarengi "moral hazzard" yang memadai. Dalam konteks ini maka nilai-nilai agama yang mencintai kehidupan menjadi suatu hal yang penting.

\section{Globalisasi dan Manajemen Stratejik Perguruan Tinggi Indonesia}

Globalisasi yang berlangsung cepat sejak era 1980-an telah menimbulkan perubahan sosial, ekonomi, politik yang sangat mendasar di berbagai belahan dunia. Globalisasi ekonomi dan revolusi teknologi informasi adalah dua kekuatan besar yang amat mempengaruhi dunia penguruan tinggi Indonesia. Kalau lembaga pendidikan tinggi nasional tidak mampu merespons tantangan globalisasi ini secara memadai, diperkirakan lembaga tersebut tidak akan mampu mempertahankan eksistensinya di masyarakat, secara pelan tapi pasti akan kehilangan perannya. Dunia pendidikan tinggi yang menganut faham universalisme ilmu pengetahuan dan teknologi sebenarnya selalu memperhatikan pertimbangan bahwa masyarakat pendidikan Indonesia adalah bagian dari masyarakat global. Dalam proses globalisasi dua kekuatan yang amat menentukan adalah kemajuan atau revolusi teknologi khususnya dalam teknologi informasi dan bioteknologi yang umumnya dikuasai perusahaan yang memiliki modal finansial.

Di masa lalu suatu bangsa selalu memiliki dan menguasai baik superstruktur dan substruktur sehingga keduanya terpisah dan dapat dibedakan dari bangsa lain. Tetapi dalam era globalisasi, superstruktur - pemerintah - tidak sepenuhnya berdaulat atas suatu negara. Substruktur suatu bangsa yang sekarang mencakup MNCs (perusahaan multinasional) mempunyai kekuatan yang luar biasa untuk memaksa pemerintah negara berdaulat untuk melaksanakan kehendaknya. Ironisnya, proses yang disebut Prof. T. Jacob sebagai penjajahan kulit putih itu terjadi dengan dukungan lembaga-lembaga internasional seperti IMF, Bank Dunia dan bahkan PBB yang pada era globalisasi ini cenderung lebih membela kepentingan negara superpower daripada negara berkembang.

Sebagai lembaga sosial yang secara bertugas mengembangkan ilmu pengetahuan dan teknologi, perguruan tinggi adalah lembaga yang paling merasakan tuntutan sosial untuk dapat melakukan perubahan. Dunia usaha, 
pemerintah dan masyarakat yang memerlukan ilmu pengetahuan baru yang berbasis teknologi informasi, bioteknologi serta ilmu multidisiplin lainnya menuntut perguruan tinggi untuk memenuhi kebutuhan mereka dalam hal ilmu pengetahuan dan teknologi yang lebih tinggi. Globalisasi di satu fihak akan memberikan kesempatan besar kepada perguruan tinggi untuk memberikan pelayanan ilmu pengetahuan dan teknologi pada masyarakat luas. Satu hal yang tidak kalah pentingnya untuk selalu diperhatikan adalah peranan perguruan tinggi Indonesia sebagai suatu lembaga yang dapat menghasilkan calon pemimpin bangsa yang bermoral dan berbudaya demokratis. Dalam konteks ini maka organisasi perguruan tinggi perlu menerapkan prinsip-prinsip manajemen strategik untuk mencapai apa yang menjadi tujuannya.

Manajemen organisasi dalam meningkatkan efektifitas dan efisiensi pendayagunaan sumber daya yang ada membutuhkan suatu model manajemen terukur. Dalam konteks manajemen modern dikenal istilah manajemen strategik yakni satu model manajemen yang dapat digunakan sebagai upaya organisasi untuk bertumbuh dan berkembang secara efektif dalam mencapai tujuan yang diharapkan. Organisasi yang baik mesti melakukan perencanaan dengan akurat dan tentu mendasari pelaksanaan kegiatan organisasinya pada perencanaan yang telah diformulasikan secara seksama.

Sharplin mendefinisikan istilah manajemen strategik sebagai proses formulasi dan implementasi rencana, dan kegiatan terkait hal hal penting, pervasif, berkesinambungan bagi suatu organisasi secara keseluruhan (Sharplin dalam Sonhadji, 2003: 51). Jadi, manajemen strategik meliputi formulasi strategi dan implementasi strategi. Jika manajemen strategik dalam dunia industri dan bisnis dimanfaatkan untuk memprediksi kecenderungan pasar dan peluang bisnis serta upaya meningkatkan daya saing, keunggulan produk dan manajemen perusahaan, maka dalam pendidikan dipakai untuk mengefektifkan berbagai sumber daya bagi pencapaian tujuan pendidikan.

Ukuran dan level dalam organisasi bervariasi, ada ukuran organisasi yang besar, sedang (menengah) dan ada pula yang kecil. Manajemen strategik bisa diterapkan ke ukuran organisasi sebesar apapun dan pada tingkat manapun didalam organisasi (within organization). Strategik mulai dilakukan pada tingkat paling atas yang disebut organization strategic hingga pada level paling bawah dalam unit-unit organisasi. Di dunia bisnis misalnya dikenal istilah corporate management strategic, sedangkan di level bawah terdapat pula manajemen strategik untuk bagian/fungsi keuangan dan seterusnya yang tidak terlepas dari strategik level atas (Sharplin, 1985: 33). 
Keberadaan perguruan tinggi Islam (UIN) yang merupakan metamorphosis dari IAIN atau STAIN tersebut memerlukan pengelolaan organisasi yang efektif dan efisien. Oleh karena itu menerapkan fungsi manajemen strategik mutlak diperlukan. Penerapan manajemen strategik memungkinkan organisasi baru (hasil perubahan) dapat terus berkembang optimal.

\section{Simpulan}

Pada bagian penutup tulisan ini akan diungkap secara singkat situasi dan kondisi UIN Maliki Malang setelah mengalami perkembangan dan perubahan status dari STAIN Malang. Lermbaga pendidikan UIN Maulama Malik Ibrahim (Maliki) Malang yang semula dalam sejarahnya merupakan filial atau perkuliahan kelas jauh dari IAIN Sunan Ampel Surabaya dalam perjalanan selanjutnya ternyata berkembang dinamis. Terbukti, UIN Maliki Malang melesat jauh meninggalkan beberapa IAIN lainnya yang masih belum mendapatkan izin dan restu merubah statusnya menjadi universitas. Ini berarti UIN telah melakukan terobosan bahkan lompatan jauh kedepan. Hal ini dilakukan tentunya setelah melakukan analisis yang cermat oleh tokoh pembaruan di UIN Malang yakni Rektor Prof. Dr. H Imam Suprayogo. Sehingga dikotomik ilmu pengetahuan di lembaga ini telah selesai dan kini tinggal bagaimana merubah tataran konsep ke tingkat operasional berlangsung secara ideal dan sesuai harapan.

Perkembangan UIN yang demikian cepat dan fenomenal itu tidak bisa dipisahkan dari kiprah sang rektor tersebut. Jikalau masih ada yang perlu dikritisi dari sosok kepemimpinan tingkat rektorat, maka kritik itu adalah tentang orientasi kepemimpinan di UIN Malang yang masih mengandalkan sosok atau figur rektor semata. Sehingga kesan tentang "one man show" tidak dapat dihindari. Citra dan anggapan ini melekat kuat di kalangan internal juga eksternal.

Mencermati fenomena diatas, maka sosialisasi visi, misi dan tradisi berikut sejumlah turunan program (program objectives) perlu dilakukan secara komprehensif dan membudaya di kalangan sivitas akademika. Kemendesakan dan kebutuhan akan adanya program sosialisasi merupakan keniscayaan mengingat kepemimpinam rektor telah beralngsung lama dan suatu saat nanti tentu beliau digantikan orang lain. Oleh karena itu demi keberlangsungan hidup organisasi dan mempertahankan kreatifitas di UIN Malang yang kerap melakukan terobosan-terobosam cerdas dan inovatif serta guna estafet kepemimpinan, maka perhatian terhadap program sosialisasi visi, misi dan 
tradisi UIN Malang menjadi urutan teratas dari tujuan yang perlu segera diwujudnyatakan.

Akhirnya, pengejawantahan nilai-nilai budaya dalam organisasi dengan menggunakan model manajemen strategik patut dan mutlak diperlukan untuk segera diterapkan guna kesinambungan pengembangan organisasi sebagaimana dikemukakan para pakar manajemen strategik seperti Sharplin, Ansoff, Edward, Pearce dan Lewis dalam Sonhadji (2003).

\section{Daftar Pustaka}

Bukhari dan Muslim. 2009. Mutiara Riyadhushalihin, Iman Al Nawawi. Jakarta: Mizan.

Dirjen Kelembagaan Agama Islam Pendidikan Islam dan Pendidikan Nasional. 2005. Jakarta: Pardigma Baru Departemen Agama.

Douglass, \& Shaikh. 2005 Defining Islamic Education: Differentiation and Applications. Current Issues Comaparative Education, Vol 3(1). Columbia.

Effendi, Sofian. Sumber: http://sofian.staff.ugm.ac.id/artikel/Effendi-mengelolaperguruan-tinggi-dalam-menghadapi-tantangan-global.pdf, diakses 30-102010).

Hanson, Mark E. 1990. Educational Administration and Organizational Behavior. Boston: Allyn and Bacon.

Huntington, Samuel P. 1998. Clash of Civilizations and the Remaking of World Order. Touchstone Books; New Ed edition

http://all-about-trick.blogspot.com/2009/06/makalah-manajemen-tentang-perubahandan.html.

http://id.wikipedia.org/wiki/Pendidikan, diakses 30 Oktober 2010.

http://insansalsabila.wordpress.com/2010/04/01/front-pembela-islam-cs-kekerasananalisis-pendekatan-psikologi-agama-zakiah-daradjat, diakses 30 Oktober 2010.

http://stidnatsir.ac.id/index.php?option=com_contentEvview $=$ articleËid $=83:$ menuj u-perguruan-tinggi-islam-antara-dawah-dan-intelektualisme-islamÉcatid=29:artikeldosenEIItemid=86 diakses 29 Oktober 2010.

http://ukpm-kronika.blogspot.com/2010/10/sekilas-perjalanan-metamorfosis-stain. 
html. diakses 30-10-2010).

http://www.bruderfic.or.id/h-59/pemikiran-ki-hajar-dewantara-tentang-pendidikan. html, diakses 30 Oktober 2010.

Kasali, Rheinald. 2006. Change. Jakarta: Gramedia.

Luthans, Fred. 1992. Organizational Behavior. Sixth edition. New York: Mc.Graw Hill.

Muhaimin. 1991. Konsepsi Pendidikan Islam, Sebuah Telaah Komponen Dasar Kurikulum. Solo: Ramadhani.

Muhaimin. 2005. Pengembangan Kurikulum Pendidikan Agama Islam: di Sekolah Madrasah dan Perguruan Tinggi. Jakarta: Raja Grafindo Persada.

Muhaimin. 2009. Konstruksi Pendidikan Islam. Jakarta: Raja Grafindo Persada.

Mujib, A \& Mudzakkir. 2006. Ilmu Pendidikan Islam. Prenada Media. Jakarta: Raja Grafindo Persada.

Owens, Robert. 1987. Organizational Behavior in Education. New Jersey: Prentice Hall.

Rice, G \& Bishoprick (1971). Conceptual Models of Organization. New York: Merdith Corp.

Robbins, Bergman, Stagg, dan Coulter. 2003. Management. 3rd edition. Melbourne: Prentice Hall.

Sharplin, Arthur. 1985. Strategic Management. Singapore: McGraw-Hill Book Co.

Sonhadji, Ahmad. 2003. Modul Manajemen Strategik: Formulasi dan Implementasi Strategi, Malang: Universitas Negeri Malang.

Suprayogo, Imam. 2004. Pendidikan Berparadigma al Quran. Malang: UIN Press.

Suwito dan Fauzan. 2005. Sejarah Sosial Pendidikan Islam. Jakarta: Prenada Media.

Suwendi. 2004. Sejarah dan Pemikiran Pendidikan Islam. Jakarta: Rajawali Press. 
Tim Penyusun Kamus Pusat Pembinaan dan Pengembangan Bahasa. Departemen P dan K. 1996. Kamus Besar Bahasa Indonesia. Jakarta: Balai Pustaka.

Republik Indonesia, Undang-Undang RI No. 20 Tahun 2003 tentang Sistem Pendidikan Nasional. Bandung: Citra Umbara.

Republik Indonesia, Departemen Agama. Terjemah Al Qurannul Karim.

Republik Indonesia, Kumpulan Peraturan Presiden Peraturan Pemerintah dan Peraturan Menteri tentang Perguruan Tinggi Agama Islam. 